\title{
HEALTH-RELATED EFFECTS OF FOOD AND NUTRITION SECURITY: AN EVIDENCE OF THE NORTHERN COMMUNITIES IN RUSSIA
}

\section{Vasilii Erokhin ${ }^{1}$}

\begin{abstract}
In the Arctic, anthropogenic pressure on the environment and progressing climate change bring together concerns over the effects of food consumption patterns on the health of the population. The goal of this study is to contribute to the development of a unified approach to revealing those effects and measuring healthy nutrition applicable across various types of circumpolar territories, populations, and consumption behavior. By applying the Delphi approach, the author builds a set of parameters along four pillars of food and nutrition security (FNS) and applied it to eight territories of the Russian Arctic. The linkages between FNS status and health are recognized by employing multiple regression analysis on the incidence rates of nutritional and metabolic disorders and diseases of the digestive system. The analysis involves: (1) urban agglomerations with prevalence of marketed food; (2) high-polluted industrial sites; (3) habitats of indigenous reindeer herders (meatbased diet); (4) coastal indigenous communities (fish-based diet). The study finds that, in Type 1 and 2 territories, health disorders are caused by poor quality of water, lack of proteins, vitamins, and minerals, and increasing share of marketed food in the diets. In Type 3 and 4 territories, higher reliance on traditional food results in lower incidence rates.
\end{abstract}

Key words: Arctic, environment, food security, nutrition, rural areas, urban agglomerations.

JEL ${ }^{2}:$ I19, Q19

\section{Introduction}

Exposure to long-range transported industrial chemicals, climate change, and diseases pose a risk to the overall health and populations of Arctic wildlife (Sonne et al., 2017) and human health in the Arctic region. A broad range of new chemicals of emerging concern (CECs) are now present in the Arctic environment, including

1 Vasilii Erokhin, Ph.D., Associate Professor, School of Economics and Management, Harbin Engineering University, China, Nantong Street no. 145, Nangang District, 150001 Harbin, China, Phone: +86-156-3670-9072, E-mail: basilic@list.ru

2 Article info: Original Article, Received: $13^{\text {th }}$ Jun 2019., Accepted: $29^{\text {th }}$ July 2019. 
persistent organic pollutants (POPs), current use pesticides, pharmaceuticals and personal care products, per- and polyfluoroalkyl substances, among others (Arctic Monitoring and Assessment Programme (AMAP, 2010)). Concentrations of some CECs are increasing in Arctic air and wildlife which indicate their potential for bioaccumulation and bio-magnification, including in food webs. In a health context, food and nutrition security (FNS) of the people living in circumpolar territories is also threatened by environmental disruptions of traditional sources of food and water (Nilsson et al., 2013). Stockholm Convention recognizes that Arctic ecosystems and indigenous communities are particularly at risk because of biomagnification of POPs, and that contamination of their traditional foods is a public health issue (United Nations Environment Programme (UNEP, 2009)).

FNS issues have been extensively discussed in relation to health in northern communities. Loring and Gerlach (2015) synthesized research on FNS in Polar Regions by studying the health impacts of the nutrition transition among indigenous peoples. Hastrup and associates (2016) analyzed how an increasing fear of contaminants had created a new sense of food and nutrition insecurity in the Arctic and addressed the emerging issue of carcinogens identified in common food-items in the North. That problem seriously affects notions of food safety in the Arctic and problems of risk and fear in relation to FNS and its effects on health. Rylander and associates (2011) also discussed the predicted effects of FNS issues on maternal and newborn health in the Arctic specifically considering their exposure and sensitivity to long-range transported contaminants.

In large parts of the Arctic, however, knowledge of particular FNS effects on health is still very limited. For many CECs, there is general lack of toxicological and other data which are needed to better understand health issues related to such compounds and for health risk assessments (AMAP, 2016). Essentially no data were available from Russia, where production volumes considered proprietary information, and spatial and temporal patterns of consumer or industrial use and emission are generally unknown. The relevance of a study of nutrition status of people living in Russia's High North is crucial in the light of a series of economic, land, and agricultural reforms of the 1990-2000s, which have substantially reduced the provision of population with biologically full-fledged local food (Ivanov, Ivanova, 2017), have deteriorated environmental and public health in the circumpolar regions, and thus have made the Russian Arctic increasingly vulnerable to food and nutrition insecurity.

In the Arctic zone of Russia, food products have historically been supplied under the framework of the Northern Deliveries program (Moe, 2014). Three world's biggest urban centers within the Arctic Circle (Murmansk city of 300,000 people, Norilsk city 
of 170,000 people and Vorkuta city of 60,000 people) heavily depend on deliveries of fruit, vegetables, grains, oil, and flour. The level of per capita consumption in the Russian Arctic remains markedly lower than in other areas of the country. According to AMAP (2017), the gap is particularly significant for milk and dairy products (about 55\% lower compared to Russia's average), eggs, potatoes, and bread (45\% lower each), and meat and meat products (30\% lower). Due to the shortages of milk and dairy products, vegetables, and fruits, there is a shift of macronutrients in the diet towards carbohydrates (an abundance of sugar, confectioneries, bread, pasta, cereals, etc.) and, therefore, a lack of almost all types of vitamins, mineral nutrients (particularly calcium, phosphorus, magnesium, potassium, iodine, zinc, fluorine, etc.), and contamination of food by pesticides, metals, antibiotics, nitrates and biological agents (Tutelyan, 1996). Traditionally meat and fish eaters, indigenous people and other northerners have so far adapted to grains and vegetables and transportation technologies to maintain a traditional subsistence way of life to some extent (Bengtson, Nikitina, 2017). Marketed foods imported into the High North of Russia and sold in stores emerged the "nutritional transition" of northerners (Egeland et al., 2011) and are now believed to be contributing to an increase in diabetes (Young et al., 2015) and other health disorders.

In recent years, there have been many attempts to use the common food security survey modules to understand the relationship between health disorders and particular FNS parameters. Those modules, however, were not originally designed for use in mixed economies of circumpolar regions where both marketed and traditional (hunted, fished, and gathered) foods contribute to peoples' diets (Ready, 2016). Power (2008) argued that the research of FNS in the Arctic would have to take into consideration the tremendous diversity of geographic locations and types of communities (urban, rural, and remote). As the effects of food and nutrition insecurity on the health of people living in the Arctic have been becoming more complex, identifying the factors which influence nutrition disruptions is crucial. Due to the damaging combination of nutritional imbalances (lack of proteins, vitamins, and minerals) and severe climatic conditions, food consumption gaps in the Arctic zone of Russia resulted in the national highest incidence of nutritional and metabolic disorders and diseases of digestive system (Bengtson, Nikitina, 2017). These two kinds of diseases have been reported by many scholars (Revich et al., 2008; Eganyan, 2013; Dudarev et al., 2013a) among the most widespread ones in both indigenous communities and urban settlements in the Arctic.

In this study, the author attempted to reveal the particular FNS factors which push the incidence rates up, as well as to elaborate policy interventions to diminish adverse impacts on health. The established approach to assessing FNS-health 
linkages may become one of the potential solutions to the existing problem of effective translation of discrepant international and national parameters into a unified measurement applicable across circumpolar territories in Arctic countries.

\section{Materials and Methods}

Since the literature search has not revealed unified FNS indicators appropriate for comparative assessment of pollution-food-health linkages in the Arctic, the author employed Delphi approach and surveyed 57 experts (32 research institutes from 11 countries, primarily, Russia and Nordic countries) in the fields of food and nutrition security, food safety, and health. The study was conducted in three phases: (1) selection of the most perspective FNS measures and their application to the territories of the Arctic zone of Russia; (2) development of FNS status scoring system and allocation of the territories; (3) identification of linkages between selected FNS parameters and health indicators.

\section{FNS parameters}

At the phase 1, the respondents were asked to suggest the most perspective FNS measures along the pillars of availability, accessibility, utilization, and stability. A set of 18 parameters was established (Table 1.).

Nearly all experts agreed that per capita criteria of adequate nutrition established by the World Health Organization (WHO) were the most appropriate measures of availability of food products essential to a healthy diet in the Arctic.

Since the primary means for obtaining and producing food in indigenous communities are provided by hunting, herding, fishing, and gathering activities, 43 respondents suggested using a presence of a hunter, a herder, or a fisherman in a family as one of the food accessibility measures. As for the marketed food, two of the commonly used FAO's measures of accessibility were agreed upon to reflect the ability of households to generate sufficient income. The selection of $A C_{1}$ and $A C_{2}$ was also based on the idea that within a monetary dimension, an access to food required a steady income in order to ensure a consistent, year-round supply of highquality goods in the stores and a ready supply of healthy wildlife to be harvested. 
Table 1. FNS status scoring system: Parameters

\begin{tabular}{|c|c|c|c|c|c|c|}
\hline \multirow{2}{*}{ FNS pillars } & \multirow{2}{*}{ Parameters } & \multirow{2}{*}{ Index } & \multirow{2}{*}{ Measure } & \multicolumn{3}{|c|}{ Score } \\
\hline & & & & $\mathbf{0}$ & 1 & 2 \\
\hline \multirow{6}{*}{ Availability } & $\begin{array}{l}\text { Per capita consumption of } \\
\text { meat products }\end{array}$ & $A V_{1}$ & $\mathrm{~kg} /$ year & $<63$ & $63-77$ & $>77$ \\
\hline & $\begin{array}{l}\text { Per capita consumption of } \\
\text { dairy products }\end{array}$ & $A V_{2}$ & $\mathrm{~kg} /$ year & $<324$ & $324-396$ & $>396$ \\
\hline & Per capita consumption of vegetables & $A V_{3}$ & $\mathrm{~kg} /$ year & $<133$ & $133-147$ & $>147$ \\
\hline & Per capita consumption of bread & $A V_{4}$ & $\mathrm{~kg} /$ year & $<114$ & $114-126$ & $>126$ \\
\hline & $\begin{array}{l}\text { Per capita consumption of fish and } \\
\text { marine mammals }\end{array}$ & $A V_{5}$ & $\mathrm{~kg} /$ year & $<7.5$ & $7.5-9.2$ & $>9.2$ \\
\hline & $\begin{array}{l}\text { Traditional food proportion } \\
\text { in a diet }\end{array}$ & $A V_{6}$ & $\%$ & $<50$ & - & $>50$ \\
\hline \multirow{3}{*}{ Accessibility } & $\begin{array}{l}\text { Proportion of food expenditures in } \\
\text { total household's expenditures }\end{array}$ & $A C_{1}$ & $\%$ & $>34$ & $28-34$ & $<28$ \\
\hline & $\begin{array}{l}\text { Proportion of population living below } \\
\text { a minimum subsistence income }\end{array}$ & $A C_{2}$ & $\%$ & $>13$ & $11-13$ & $<11$ \\
\hline & $\begin{array}{l}\text { Proportion of households with a hunt- } \\
\text { er, a herder, or a fisherman in a family }\end{array}$ & $A C_{3}$ & $\%$ & $<50$ & - & $>50$ \\
\hline \multirow{6}{*}{ Utilization } & $\begin{array}{l}\text { Incidence rate - nutritional and meta- } \\
\text { bolic disorders }\end{array}$ & $U T_{1}$ & per 1,000 & $>16$ & $13-16$ & $<13$ \\
\hline & $\begin{array}{l}\text { Incidence rate - diseases of the diges- } \\
\text { tive system }\end{array}$ & $U T_{2}$ & per 1,000 & $>35$ & $29-35$ & $<29$ \\
\hline & Per capita wastewater discharge & $U T_{3}$ & $\mathrm{~m}^{3} /$ year & $>110$ & $90-110$ & $<90$ \\
\hline & $\begin{array}{l}\text { Percentage of households having run- } \\
\text { ning water available in their homes }\end{array}$ & $U T_{4}$ & $\%$ & $<76$ & $76-95$ & $>95$ \\
\hline & $\begin{array}{l}\text { Percentage of households having } \\
\text { access to the quality assured sources } \\
\text { of water }\end{array}$ & $U T_{5}$ & $\%$ & $<25$ & $25-30$ & $>30$ \\
\hline & Air pollutant emissions & $U T_{6}$ & tons $/ \mathrm{km}^{2}$ & $>1.19$ & $0.97-1.19$ & $<0.97$ \\
\hline \multirow{3}{*}{ Stability } & $\begin{array}{l}\text { Extreme weather conditions when a } \\
\text { traffic with the mainland is interrupted }\end{array}$ & $S T_{1}$ & days/year & $>60$ & $30-60$ & $<30$ \\
\hline & Safety net programs & $S T_{2}$ & programs & 0 & - & $\geq 1$ \\
\hline & Food availability support programs & $S T_{3}$ & programs & 0 & - & $\geq 1$ \\
\hline
\end{tabular}

Source: Author's development.

In relation to utilization pillar, 39 experts reported waterborne infectious diseases among the people living in the circumpolar territories as a critical issue. A parameter of air pollutant emissions was suggested by 34 respondents.

As for stability, the respondents emphasized extreme weather conditions, energy scarcity, and economic and social disruption as the factors of adverse effects on the stability of food supply in the circumpolar territories.

FNS parameters were calculated on a per-territory basis in eight areas included in the Arctic zone of Russia (Figure 1.). 
Figure 1. Territories of the Arctic zone of Russia included in the study

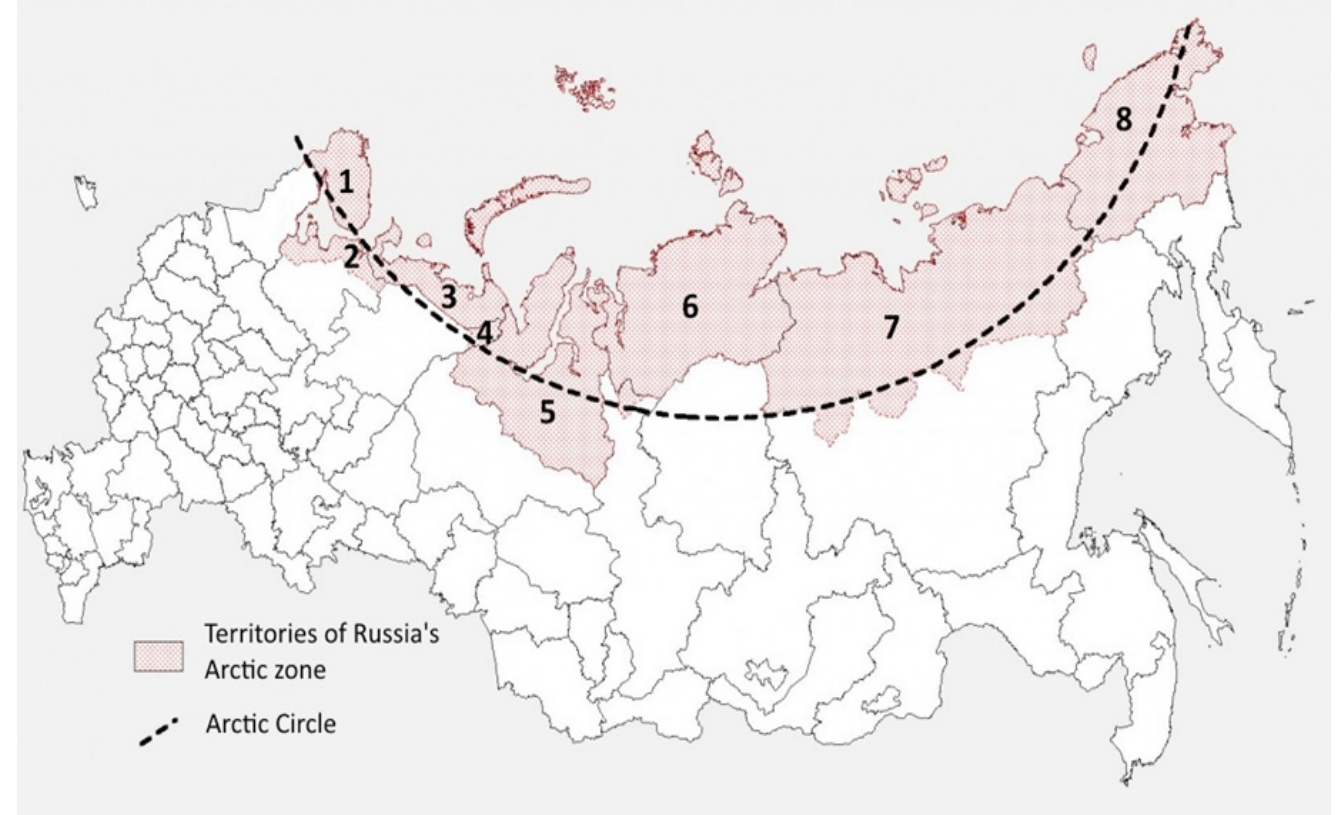

Source: Author's development.

Note: (1) Murmansk region; (2) Arkhangelsk region territories: Arkhangelsk, Mezensk municipal area, Novaya Zemlya, Novodvinsk, Onezh municipal area, Primorsk municipal area, Severodvinsk; (3) Nenets Autonomous District; (4) Komi Republic territories: Vorkuta municipal area; (5) Yamal-Nenets Autonomous District; (6) Krasnoyarsk Krai territories: Norilsk, Taimyr Dolgan-Nenets municipal area, Turukhansk district; (7) Republic of Sakha (Yakutia) territories: Allaikhovsky district, Anabar national (Dolgan-Evenk) district, Bulunsky district, Nizhnekolymsky district, Ust-Yansky district; (8) Chukotka Autonomous District.

The data were obtained from the Federal Service of State Statistics of the Russian Federation, as well as from the author's calculations.

\section{FNS status scoring system}

So far, cross-country comparisons of pollution-food-health issues in the Arctic have been hindered by the lack of comparable international data as many of the indicators reported in national databases have not matched and have not been readily available in national statistical sources. At phase 2 , the author attempted to overcome that by translating both international and national average indicators into a unified FNS status scoring system.

The implementation of the FNS status scoring system starts with a rating of the parameters on the scale from 0 (the lowest) to 2 (the highest), (Table 2.). At this stage, 32 respondents recommended setting a threshold level of security within a 
$10 \%$ corridor around respective $\mathrm{WHO}$, international, and national average criteria. On each of the parameters, security is achieved at score 1 (100\% of respected value). A value below $90 \%$ of a threshold is scored 0 (insecurity situation), while that above $110 \%$ is scored 2 (high security).

Table 2. FNS status scoring system: pillars

\begin{tabular}{|l|c|c|c|c|}
\hline \multicolumn{1}{|c|}{ FNS pillars } & $\begin{array}{c}\text { Critical insecu- } \\
\text { rity }\end{array}$ & Insecurity & Security & High security \\
\hline Availability & $0.0-2.9$ & $3.0-5.9$ & $6.0-9.9$ & $10.0-12.0$ \\
\hline Accessibility & $0.0-0.9$ & $1.0-2.9$ & $3.0-4.9$ & $5.0-6.0$ \\
\hline Utilization & $0.0-2.9$ & $3.0-4.9$ & $5.0-9.9$ & $10.0-12.0$ \\
\hline Stability & $0.0-1.9$ & $2.0-3.9$ & $4.0-5.9$ & 6.0 \\
\hline Total FNS & $0.0-8.9$ & $9.0-17.9$ & $18.0-30.9$ & $31.0-36.0$ \\
\hline
\end{tabular}

Source: Author's development.

To make cross-country comparisons possible, the diversity of pollution-foodhealth relations was addressed by categorizing the territories based on the respective scores of FNS parameters:

1. Type 1: Territories adjacent to urban agglomerations, high share of market food in the diets (low $A V_{6} ; A V_{1}-A V_{5}, A C_{1}$, and $A C_{2}$ within a security threshold).

2. Type 2: Territories adjacent to industrial agglomerations, high pollution (high $U T_{3}$ and $U T_{6}$; low $U T_{4}$ and $\left.U T_{5}\right)$.

3. Type 3: Remote inland areas, high share of meat in traditional diets (high $A V_{l}$, $A V_{6}$, and $A C_{3}$; low $A V_{3}-A V_{5}$ and $S T_{1}$ ).

4. Type 4: Coastline territories, high share of fish and marine mammals in traditional diets (high $A V_{5}, A V_{6}$, and $A C_{3}$; low $A V_{1}-A V_{4}$ and $S T_{1}$ ).

FNS parameters and then territories were rated on the scale between critical insecurity and high security.

Regression analysis

At phase 3, an attempt was made to capture overlapping FNS availability, accessibility, utilization, and stability dimensions and understand their impacts on the health of people living in different types of circumpolar territories and following various types of food consumption patterns. The author employed multiple regression analysis to reveal the separate effects of sixteen regressors $X_{i, 1-16}$ on $U T_{1}$ and $U T_{2}$. The variables with the highest positive, positive, negative and the most negative effects on $U T_{1}$ and $U T_{2}$ were revealed for the eight territories of the Arctic zone of Russia to demonstrate the workability of the three-stage approach for both national-specific analysis and cross-country comparisons. 


\section{Results}

Categorization of the territories based on the scores of FNS parameters allowed grouping them into four types (Figure 2. and Table 3.).

Figure 2. Types of Russian Arctic territories on the scores of FNS parameters

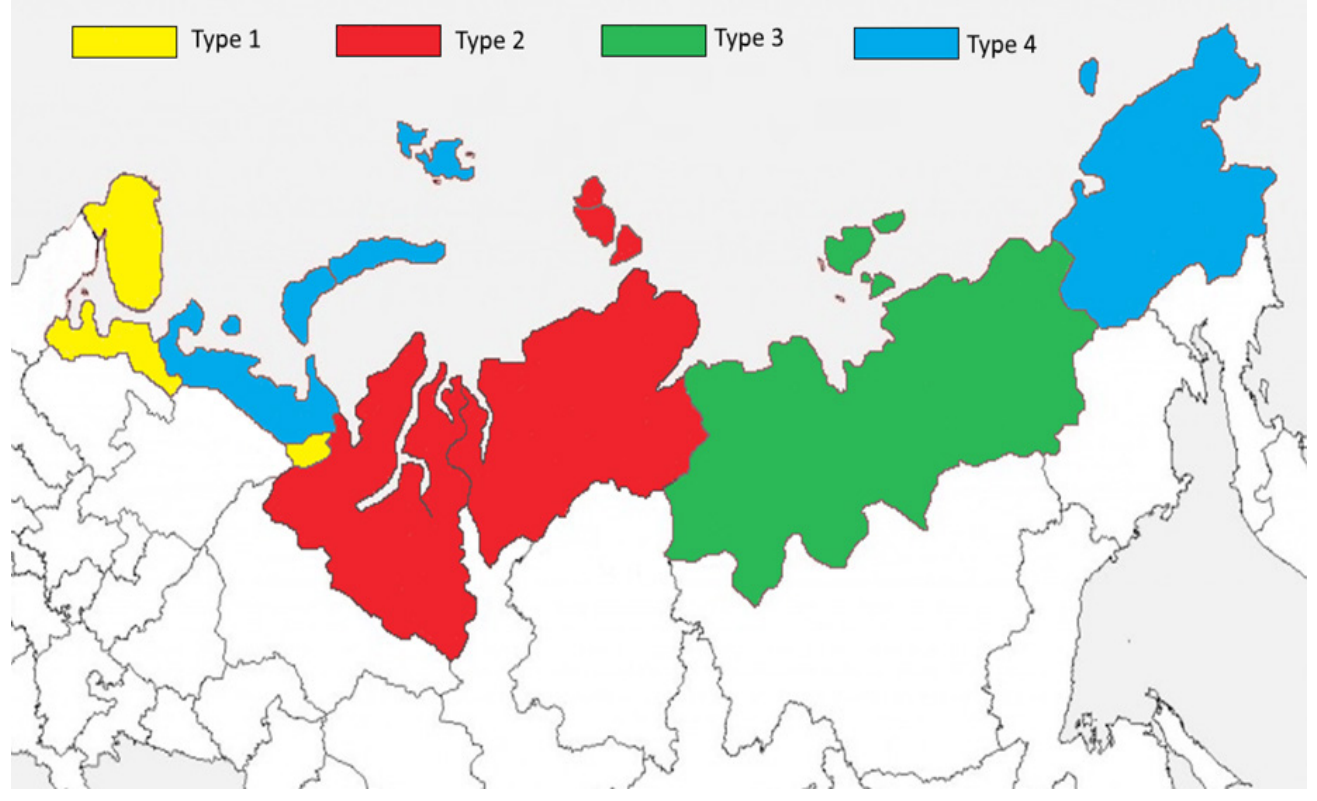

Source: Author's development.

In Type 1 territories, people have predominantly westernized type of nutrition with a high proportion of marketed products and low share of traditional foods in the diets. In 2016, in Murmansk region, Arkhangelsk region, and the Komi Republic, the incidence rates of nutritional and metabolic disorders were 17.8, 13.6, and 18.7 per 1,000 inhabitants, respectively (Russia's national average was 13.9 per 1,000). The incidence rates of the diseases of the digestive system were substantially above the national average in Arkhangelsk region (55.7 per 1,000 compared to 35.6 per 1,000 as the national average) and Komi Republic $(41.0$ per 1,000$)$ and below the national average in Murmansk region (32.8 per 1,000). 
Table 3. Territories of the Arctic zone of Russia: FNS pillars scores, average in 1996-2016.

\begin{tabular}{|c|c|c|c|c|c|c|}
\hline \multirow{2}{*}{$\begin{array}{l}\text { Area } \\
\text { type }\end{array}$} & \multirow{2}{*}{ Territory } & \multicolumn{4}{|c|}{ FNS pillars } & \multirow{2}{*}{ FNS status } \\
\hline & & Availability & Accessibility & Utilization & Stability & \\
\hline \multirow{3}{*}{ Type 1} & Murmansk region & Insecurity & Insecurity & Security & Security & Insecurity \\
\hline & Arkhangelsk region & $\begin{array}{l}\text { Critical } \\
\text { insecurity }\end{array}$ & $\begin{array}{l}\text { Critical } \\
\text { insecurity }\end{array}$ & Insecurity & Security & Insecurity \\
\hline & Komi Republic & $\begin{array}{l}\text { Critical } \\
\text { insecurity }\end{array}$ & $\begin{array}{l}\text { Critical } \\
\text { insecurity }\end{array}$ & $\begin{array}{l}\text { Critical } \\
\text { insecurity }\end{array}$ & Insecurity & $\begin{array}{l}\text { Critical } \\
\text { insecurity }\end{array}$ \\
\hline \multirow[t]{2}{*}{ Type 2} & $\begin{array}{l}\text { Yamal-Nenets } \\
\text { Autonomous District }\end{array}$ & Insecurity & Security & Security & Security & Security \\
\hline & Krasnoyarsk Krai & Insecurity & Insecurity & Security & Insecurity & Insecurity \\
\hline Type 3 & $\begin{array}{l}\text { Republic of Sakha } \\
\text { (Yakutia) }\end{array}$ & Security & Insecurity & Insecurity & Insecurity & Insecurity \\
\hline \multirow{2}{*}{ Type 4} & $\begin{array}{l}\text { Chukotka Autonomous } \\
\text { District }\end{array}$ & Insecurity & Security & Security & Insecurity & Insecurity \\
\hline & $\begin{array}{l}\text { Nenets Autonomous } \\
\text { District }\end{array}$ & Insecurity & High security & Insecurity & Security & Insecurity \\
\hline
\end{tabular}

Source: Author's development.

In Type 2 territories, high per capita water discharge and air pollutant emissions are registered. The percentage of households with access to the quality assured sources of water is low. In Yamal-Nenets Autonomous District, the incidence rates of both nutritional disorders and diseases of the digestive system are extremely high compared to the national average - 19.3 and 56.3 per 1,000 respectively. In Krasnoyarsk Krai, less intensively explored by Russian hydrocarbon and mineral companies, the incidence rates are lower -13.8 per 1,000 for nutritional disorders and 38.7 per 1,000 for the diseases of the digestive system.

In Type 3 and 4 territories, diets of people are more traditional compared to the western parts of the Russian North, with a predominance of reindeer meat, fish, and marine mammals. The Yakuts are historically semi-nomadic hunters engaged in animal husbandry focusing on reindeer herding. Traditionally, their diets are meatbased with low portion of milk and dairy products, vegetables, and bread. People in Type 4 territories also rely on traditional food. Per capita consumption of meat and dairy products, vegetables, and bread is low compared to fish, particularly, in Chukotka, where marketed food is delivered by air and thus extremely expensive. In terms of nutritional and metabolic disorders, the incidence rate in Chukotka was only 12.9 per 1,000 in 2016, while in the Nenets Autonomous District (30.7 per $1,000)$ it almost approached Russia's national average. In terms of the diseases of digestive system, the gap is not that big -59.5 and 68.9 per 1,000 in Chukotka and the Nenets Autonomous District, respectively, much above the national average of 35.6 per 1,000 . 
Such a diversity of incidence rates in the territories with roughly similar food consumption patterns can be explained by an influence of other factors apart from the diets, particularly, low quality of water (Table 4.).

Table 4. Revealed FNS-health interrelationships

\begin{tabular}{|c|c|c|c|c|c|c|}
\hline \multirow{2}{*}{$\begin{array}{l}\text { Area } \\
\text { type }\end{array}$} & \multirow[b]{2}{*}{ Territories } & \multirow[b]{2}{*}{ Regressands } & \multicolumn{4}{|c|}{ Regressors and their effects on health } \\
\hline & & & $\begin{array}{l}\text { Highest } \\
\text { positive }\end{array}$ & Positive & Negative & $\begin{array}{c}\text { Most } \\
\text { negative }\end{array}$ \\
\hline \multirow{6}{*}{$\begin{array}{c}\text { Type } \\
1\end{array}$} & \multirow{2}{*}{$\begin{array}{l}\text { Murmansk } \\
\text { region }\end{array}$} & $U T_{1}$ & $A V_{5}$ & $\begin{array}{l}A V_{1}, A V_{3}, A V_{4}, U T_{5}, \\
S T_{2}\end{array}$ & $\begin{array}{l}A V_{2}, A V_{6}, A C_{1}, A C_{2}, A C_{3^{\prime}}, \\
U T_{3}, U T_{6}, S T_{1}\end{array}$ & $U T_{4}$ \\
\hline & & $U T_{2}$ & $U T_{5}$ & $\begin{array}{l}A V_{3}, A V_{5}, A V_{6}, A C_{3}, \\
S T_{2}\end{array}$ & $\begin{array}{l}A V_{1}, A V_{2}, A V_{4}, A C_{1}, A C_{2}, \\
U T_{3}, U T_{6}, S T_{1}\end{array}$ & $U T_{4}$ \\
\hline & \multirow{2}{*}{$\begin{array}{l}\text { Arkhangelsk } \\
\text { region }\end{array}$} & $U T_{1}$ & $A V_{l}$ & $\begin{array}{l}A V_{4}, A V_{5}, A V_{6}, A C_{3}, \\
U T_{5}, S T_{2}\end{array}$ & $\begin{array}{l}A V_{2}, A V_{3}, A C_{1}, A C_{2}, U T_{3}, \\
U T_{6}, S T_{1}\end{array}$ & $U T_{4}$ \\
\hline & & $U T_{2}$ & $U T_{5}$ & $\begin{array}{l}A V_{1}, A V_{2}, A V_{4}, A V_{5} \\
A C_{3}, S T_{2}\end{array}$ & $\begin{array}{l}A V_{3}, A V_{6,} A C_{1}, A C_{2}, U T_{3}, \\
U T_{6}, S T_{1}\end{array}$ & $U T_{4}$ \\
\hline & \multirow{2}{*}{$\begin{array}{l}\text { Komi } \\
\text { Republic }\end{array}$} & $U T_{1}$ & $A V_{5}$ & $\begin{array}{l}A V_{2}, A V_{4}, A V_{6}, A C_{3}, \\
U T_{5}, S T_{2}, S T_{3}\end{array}$ & $\begin{array}{l}A V_{1}, A V_{3}, A C_{1}, A C_{2}, U T_{3^{\prime}} \\
U T_{6}, S T_{1}\end{array}$ & $U T_{4}$ \\
\hline & & $U T_{2}$ & $A V_{I}$ & $\begin{array}{l}A V_{4}, A V_{5}, A C_{3}, U T_{5}, \\
S T_{2}, S T_{3}\end{array}$ & $\begin{array}{l}A V_{2}, A V_{3}, A V_{6}, A C_{1}, A C_{2}, \\
U T_{3}, U T_{6}, S T_{1}\end{array}$ & $U T_{4}$ \\
\hline \multirow{4}{*}{$\begin{array}{c}\text { Type } \\
2\end{array}$} & \multirow{2}{*}{$\begin{array}{l}\text { Yamal- } \\
\text { Nenets } \\
\text { Autonomous } \\
\text { District }\end{array}$} & $U T_{1}$ & $A V_{2}$ & $\begin{array}{l}A V_{4}, A V_{5}, A V_{6}, A C_{1}, \\
U T_{5}, S T_{2}, S T_{3}\end{array}$ & $\begin{array}{l}A V_{3}, A C_{2}, A C_{3}, U T_{3}, U T_{4} \\
U T_{6}, S T_{1}\end{array}$ & $A V_{1}$ \\
\hline & & $U T_{2}$ & $A V_{2}$ & $\begin{array}{l}A V_{4}, A V_{5}, A C_{l}, A C_{3,} \\
U T_{4}, U T_{5}, S T_{2}, S T_{3}\end{array}$ & $\begin{array}{l}A V_{3}, A V_{6}, A C_{2}, U T_{3}, U T_{6}, \\
S T_{1}\end{array}$ & $A V_{1}$ \\
\hline & \multirow{2}{*}{$\begin{array}{l}\text { Krasnoyarsk } \\
\text { Krai }\end{array}$} & $U T_{1}$ & $\mathrm{AV}_{4}$ & $\begin{array}{l}A V_{1}, A V_{2}, U T_{5}, S T_{2}, \\
S T_{3}\end{array}$ & $\begin{array}{l}A V_{3}, A V_{6}, A C_{1}, A C_{2}, A C_{3^{\prime}}, \\
U T_{3}, U T_{4}, U T_{6}, S T_{1}\end{array}$ & $A V_{5}$ \\
\hline & & $U T_{2}$ & $\mathrm{AV}_{4}$ & $A V_{2}, U T_{5}, S T_{2}, S T_{3}$ & $\begin{array}{l}A V_{l}, A V_{3}, A V_{S}, A C_{l}, A C_{2}, \\
A C_{3}, U T_{3}, U T_{4}, U T_{6}, S T_{l}\end{array}$ & $A V_{6}$ \\
\hline \multirow{2}{*}{$\begin{array}{c}\text { Type } \\
3\end{array}$} & \multirow{2}{*}{$\begin{array}{l}\text { Republic } \\
\text { of Sakha } \\
\text { (Yakutia) }\end{array}$} & $U T_{1}$ & $A C_{3}$ & $\begin{array}{l}A V_{l}, A V_{6}, A C_{1}, A C_{2}, \\
U T_{4}, U T_{5}, S T_{3}\end{array}$ & $\begin{array}{l}A V_{2}, A V_{4}, A V_{5}, U T_{3}, U T_{6}, \\
S T_{I}\end{array}$ & $\mathrm{AV}_{3}$ \\
\hline & & $U T_{2}$ & $A C_{3}$ & $\begin{array}{l}A V_{1}, A V_{6}, A C_{1}, A C_{2}, \\
U T_{4}, U T_{5}, S T_{3}\end{array}$ & $\begin{array}{l}A V_{2}, A V_{3}, A V_{4}, U T_{3}, U T_{6}, \\
S T_{1}\end{array}$ & $A V_{5}$ \\
\hline \multirow{4}{*}{$\begin{array}{c}\text { Type } \\
4\end{array}$} & \multirow{2}{*}{$\begin{array}{l}\text { Chukotka } \\
\text { Autinomous } \\
\text { District }\end{array}$} & $U T_{l}$ & $A V_{5}$ & $\begin{array}{l}A V_{2}, A V_{4}, A V_{6}, A C_{3}, \\
U T_{4}, U T_{5}, S T_{3}\end{array}$ & $\begin{array}{l}A V_{3}, A C_{1}, A C_{2}, U T_{3}, U T_{6}, \\
S T_{1}\end{array}$ & $A V_{I}$ \\
\hline & & $U T_{2}$ & $U T_{5}$ & $\begin{array}{l}A V_{2}, A V_{5}, A V_{6}, A C_{3}, \\
U T_{4}, S T_{2}, S T_{3}\end{array}$ & $\begin{array}{l}A V_{1}, A V_{3}, A V_{4}, A C_{1}, A C_{2}, \\
U T_{3}, U T_{6}\end{array}$ & $S T_{1}$ \\
\hline & \multirow{2}{*}{$\begin{array}{l}\text { Nenets } \\
\text { Autonomous } \\
\text { District }\end{array}$} & $U T_{l}$ & $A C_{3}$ & $\begin{array}{l}A V_{2}, A V_{3}, A V_{4}, A V_{5}, \\
A V_{6}, U T_{4}, U T_{5}, S T_{2}, \\
S T_{3}\end{array}$ & $A C_{l}, A C_{2}, U T_{3}, U T_{6}, S T_{1}$ & $A V_{l}$ \\
\hline & & $U T_{2}$ & $\mathrm{AV}_{3}$ & $\begin{array}{l}A V_{2}, A V_{4}, A V_{5}, A V_{6}, \\
A C_{3}, U T_{4}, U T_{5}, S T_{2}, \\
S T_{3}\end{array}$ & $A V_{1}, A C_{1}, A C_{2}, U T_{6}, S T_{1}$ & $U T_{3}$ \\
\hline
\end{tabular}

Source: Author's development.

Type 1 territories are those with the biggest per capita wastewater discharge among the areas under study. Being predominantly urban and sub-urban agglomerations, Type 1 territories have the high coverage of households by public water supply 
(over $80 \%$ ), but the majority of water supply facilities have not been properly repaired, cleaned and disinfected for a long time (Dudarev et al., 2013b). Due to the high water and air pollution load, consumption of wildlife food as well as hunting and fishing increase incidence rates, that is why a westernized diet of people in urbanized areas is rather good than the bad solution of FNS situation for Type 1 territories.

In the industrialized territories of Type 2, environmental pollution has resulted in the even more negative effects of traditional diets on health. The increase of a share of meat, fish, and vegetables in the consumption basket leads to the growth of nutritional and metabolic disorders and diseases of the digestive system. Consumption of market food may give a positive health effect, but the economic accessibility of such food is roughly secured in Yamal-Nenets Autonomous District only. In the northern parts of Krasnoyarsk Krai, the proportion of the population living below a minimum subsistence income is one of the highest in the Russian Arctic. As the economic accessibility of food decreases, nutritional habits of consumers change from high-fat animal products to bread, macaroni products, and low-nutritious starches. Hunting and fishing contribute to the diversification of the diets, but negatively affect health because of high pollution of water sources and air.

In Type 3 territories, on the contrary, the highest in Russian Arctic proportion of the population living below a minimum subsistence income has a positive influence on health. Poverty forces people to seek a substitution to market food in hunting and fishing. Lower environmental pollution along with the remoteness from the big industrial agglomerations result in healthier wildlife resources. Indigenous peoples inhabiting the northern parts of the Republic of Sakha (Yakutia) are predominantly reindeer herders. They live in self-subsistence communities and do not consume much of the ecdemic food. Due to the remoteness from the mainland and low stability of food supply (frequent extreme weather conditions when a traffic with the mainland is interrupted), available vegetables, dairy products, bread, and fish are usually frozen and with a high content of food preservatives to extend the shelf life. Health effects of such foods are adverse.

Similar to Type 3 , the population in Type 4 territories depends on traditional food, particularly, fishing. As indigenous peoples in coastal territories are unaccustomed to meat, an increase in its consumption has a negative effect on the incidence rates of nutritional and metabolic disorders and diseases of the digestive system. On the contrary, an increase of consumption of fish and marine mammals obtained from the quality assured sources of water has a positive health effect. The Nenets Autonomous District is located closer to the European part of Russia, therefore even in the indigenous communities, as distinct from Chukotka, the diets are 
more westernized and the people are more accustomed to market food. However, due to the low economic accessibility of such food $(10.5 \%$ of the population live below a minimum subsistence income), per capita consumption of meat and dairy products and vegetables is below of both the WHO's criteria of adequate nutrition and Russia's national average. Every increase in consumption of those products, particularly, vegetables, may have a positive effect on health.

\section{Discussion and FNS Implications}

The territories of the Russian Arctic are those with the lowest per capita consumption of major staple foods among the regions of the country. During the period of economic reforms in Russia, in the High North, per capita production of meat decreased from $22.6 \mathrm{~kg}$ in 1990 down to $13.6 \mathrm{~kg}$ in 2016, milk from 108 $\mathrm{kg}$ down to $25 \mathrm{~kg}$, vegetables from $6 \mathrm{~kg}$ down to $0.5 \mathrm{~kg}$, respectively (Ivanov, Ivanova, 2017). Undiversified diets also have adverse effects on health. In particular, a dreary meat-based diet in the availability-secured Yakutia resulted in the lowest in Russian Arctic incidence rate of nutritional and metabolic disorders, but at the same time, in the highest incidence rates of the diseases of digestive system. Heavy dependence on a particular industry (reindeer herding and fishing in case of Type 3 and Type 4 territories, respectively) may further decrease options for diversification of diets and pose human health risks, which was also reported by Lambden and associates (2006), Ford (2009), Goldhar and associates (2010) and Wesche and Chan (2010) in the cases of the circumpolar territories of Canada and Greenland.

Health effects of traditional food consumption are rather diverse. On the one hand, traditional food is a crucial source of subsistence and major component of a daily ration for many people in the Arctic. Changing access to, availability of, and quality of traditional food resources has implications for quality of diet since nutritional implications of lower traditional food intake include likely reductions in iron, zinc, protein, vitamin D, and omega-3 fatty acids, among others (Wesche, Chan, 2010). On the other hand, this study demonstrated that increase in a proportion of traditional food in a diet might have a positive effect on decrease of nutritional disorders and diseases of digestive system in Type 3 and Type 4 territories only, while in the environmentally polluted Type 1 and 2 territories, both consumption of traditional food and hunting/fishing had negative effects on health. This finding supports the results of previous studies by Vinokurova (2011), Greaves (2016) and Ignateva (2018) who all concluded that pollution had threatened the diets and health in the Russian Arctic. 
The study shows that environmental effects have to be assessed in parallel with economic factors. Among others, such a conclusion supports the findings of Willows (2005), Rylander et al. (2011) and Ivanov and Ivanova (2017). Low level of income and high food costs both result in changing diets and neglect of healthy eating (Ford, 2009; Wesche, Chan, 2010). Lambden and associates (2006) and Goldhar and associates (2010) demonstrated that traditional diets were adversely affected by high costs of hunting and fishing, tightening food sharing networks, and hunting and fishing regulations. In case of the urbanized and industrialized territories of Type 1 and 2, the study demonstrated that poverty and growing proportion of food expenditures in total households' expenditures decreased the diversity of the diets and their nutritional content and thus negatively affected health parameters.

The diversity of health influencers has to be properly reflected in the development of the interventions to improve the nutritional status of people. The study proved that the interventions had to be adjusted to the specific set of factors in each particular territory as well as to the food choices of target groups of consumers and patterns of food availability, accessibility, utilization, and stability.

Since the increase in consumption affects selected health parameters in a positive way, policy interventions have to be targeted at every possible improvement of food availability. Among the solutions could be the development of agricultural production locally, including organic farming, animal husbandry improvements and new technologies in the fields of livestock breeding and aquaculture, animal health and vaccination and veterinary. Producing locally takes a lot of the insecurity out of supply chain. Moreover, locally produced food may result in an increased quality, as there is less risk of damage during transport or storage. Greenhouse horticulture is a solution to combat low per capita consumption of vegetables, particularly, in Arkhangelsk region, Nenets Autonomous District, and the Komi Republic. Climate change and warmer weather in the Arctic allow farmers to grow vegetables, grains, herbs, and other plants that have typically been planted in more temperate fields.

Increase in supply has to be accompanied by an adequate growth of accessibility of staple foods for the great majority of Arctic populations, particularly, urban and rural poor. For vulnerable groups of people, food availability interventions should be accompanied by food supply and cash income generating measures. In Type 1 and Type 4 territories, accessibility may be improved through the targeted food subsidies to urban and rural poor, for instance, fair price shops and subsidies for buying locally produced food. In Type 2 territories, where the share of population living below a minimum subsistence level is high, food supply measures should include employment generation schemes, the important forms of targeted interventions to augment the incomes of poor un- and under-employed people in urban and rural areas 
(Bokeloh, 2010). The prospective schemes are seasonal wage (food) employment to supplement a temporary loss of income during winter time and regular projects designed to involve available labor in the construction of infrastructure and resourceexploration facilities. In Type 3 territories, employment opportunity programs and target subsidies should be aimed at the increase of the involvement of people to traditional industries of reindeer husbandry, hunting, and fishing.

While employment schemes prevent people from becoming dependent on food assistance, some food availability programs are still needed to ensure food and nutrition security of children, elderly and disabled persons, and pregnant and lactating women. In Type 2, Type 3, and Type 4 territories, such measures should include free distribution of relief rations and supplementary feeding programs. Bokeloh (2010) points up the fact that relief food is most effectively distributed where it is channeled through established community structures. In the case of urban agglomerations, resource-exploration sites, or established settlements of indigenous peoples, efforts should be made to keep the people in their community environments by providing assistance there. However, due to the remoteness and poor transport accessibility of many settlements (primarily of those located in Type 3 and Type 4 areas), high risk of their temporary isolation from the mainland due to the extreme weather conditions, as well as the nomadic way of life of many indigenous populations, food availability programs involve a high risk of food insecurity. Therefore, in Type 3 and Type 4 territories, relief rations and supplementary feeding programs should be accompanied by the establishment of food stocks to avoid delays and irregular food supplies in the times of extreme weather conditions.

Quality of public water supply system has to be improved. Upgrade, cleaning, and sanitation of public water supply facilities are required in Arkhangelsk and Murmansk regions and Komi Republic. In Type 1 rural areas, soil and water reclamation measures are required to protect the aquifers from pollution from surface areas. In Type 2 territories, environmental pollution is the most critical threat to public health. The problem must be addressed by the air pollution control measures and permanent soil and water reclamation to introduce increasingly restrictive emission regulations and encourage resource-exploration companies to utilize environment-friendly technologies.

\section{Conclusion}

In this paper, the author attempted to convey the existing complexity of problems faced by the northerners today as food security was but one of several, often interrelating issues affecting their health. The study investigated how various 
parameters of food availability, accessibility, utilization, stability, and safety along with environmental pollution factors were interrelated with food supply and consumption, intake of nutrients, and, ultimately, selected health indicators in the Arctic. The diversity of FNS patterns and their health effects was addressed by two approaches. First, the fourfold pillar approach to FNS-health interrelationships allowed for an analysis of the variations within FNS dimensions and thus made different types of territories comparable on the per pillar basis. Second, the author grouped the territories into four types: urbanized with a domination of market food in the diets, industrial with high level of air and water pollution, inland rural areas with high proportion of meat in traditional diets, and coastline rural areas with high proportion of fish and marine mammals in traditional diets. Relationships between the regressands and corresponding regressors were discovered in view of the alternations between the highest positive, positive, negative, and the most negative influences on the dependent variables for each territory under study.

The study attempted to bridge a gap in studying interrelationships between FNS and its major effects on health in the Arctic. Although an employment of the Delphi approach resulted in the development of a set of FNS parameters reliable in the Arctic health context, the issue remains open-ended and discussible. The constructed regression model demonstrated that almost $90 \%$ of the variations in incidence rates were explained by the selected variables. That actually means that the proposed scoring may become one of the solutions to the existing problem of effective translation of discrepant international and national FNS parameters into a unified system applicable across Nordic countries. However, due to the ongoing process of environmental and economic change in the Arctic, a further focus on finding the most feasible indicators of food and nutrition insecurity problem could place the issue in the larger context of social-ecological change that affects the resilience of the Arctic and health and well-being of its inhabitants. Climate change, rising food prices, and oil, gas, and mineral development require reevaluation of how wildlife and other resources are managed in the Arctic, as well as how such rapid changes might negatively impact health. Progressing nutritional transition suggests that future studies and FNS interventions should consider the affordability of healthy retail food choices, in addition to increasing the availability of traditional foods.

\section{Acknowledgment}

This work was supported by the National Social Science Fund of China under Grant 18BGJ004. 


\section{References}

1. AMAP (2010). AMAP Assessment 2009: Persistent Organic Pollutants (POPs) in the Arctic. Science of the Total Environment Special Issue, Arctic Monitoring and Assessment Programme (AMAP), 408:2851-3051.

2. AMAP (2016). AMAP Assessment 2016: Chemicals of Emerging Arctic Concern. Arctic Monitoring and Assessment Programme (AMAP), Oslo, Norway.

3. AMAP (2017). Adaptation Actions for a Changing Arctic: Perspectives from the Bering-Chukchi-Beaufort Region. Arctic Monitoring and Assessment Programme (AMAP), Oslo, Norway.

4. Bengtson, J. L., Nikitina, E. (2017). Impacts and Consequences for Northern Communities and Society. In: Nikitina, E., Outridge, P., Walsh J. E. (Eds.), Adaptation Actions for a Changing Arctic: Perspectives from the Bering-ChukchiBeaufort Region, AMAP, Oslo, Norway, pp. 125-152.

5. Bokeloh, G. (2010). Actions/Interventions to Improve Food and Nutrition Security at Meso and Micro Level. In: Klennert, K. (Ed.), Achieving Food and Nutrition Security: Actions to Meet the Global Challenge - A Training Course Reader, Inwent, Bonn, Germany, pp. 145-180.

6. Dudarev, A. A., Alloyarov, P. R., Chupakhin, V. S., Dushkina, E. V., Sladkova, Y. N., Dorofeyev, V. M., Kolesnikova, T. A., Fridman, K. B., Nilsson, L. M., Evengard, B. (2013a). Food and Water Security Issues in Russia I: Food Security in the General Population of the Russian Arctic, Siberia and Far East, 2000-2011. International Journal of Circumpolar Health, 72(1):1-10, doi:10.3402/ijch. v72i0.21848

7. Dudarev, A. A., Dushkina, E. V., Sladkova, Y. N., Alloyarov, P. R., Chupakhin, V. S., Dorofeyev, V. M., Kolesnikova, T. A., Fridman, K. B., Evengard, B., Nilsson, L. M. (2013b). Food and Water Security Issues in Russia II: Water Security in General Population of Russian Arctic, Siberia and Far East, 20002011. International Journal of Circumpolar Health, 72(1):1-11, doi:10.3402/ijch. v72i0.22646

8. Eganyan, R. (2013). Nutritional Characteristics in Dwellers of the Far North of Russia: A Review of Literature. The Russian Journal of Preventive Medicine and Public Health, 5:41-47.

9. Egeland, G. M., Johnson-Down, L., Cao, Z. R., Sheikh, N., Weiler, H. (2011). Food Insecurity and Nutrition Transition Combine to Affect Nutrient Intakes in Canadian Arctic Communities. Journal of Nutrition, 141:1746-1753.

10. Ford, J. D. (2009). Vulnerability of Inuit Food Systems to Food Insecurity as a 
Consequence of Climate Change: A Case Study from Igloolik, Nunavut. Regional Environmental Change, 9(2):83-100.

11. Goldhar, C., Ford, J. D., Berrang-Ford, L. (2010). Prevalence of Food Insecurity in a Greenlandic Community and the Importance of Social, Economic and Environmental Stressors. International Journal of Circumpolar Health, 69:285-303.

12. Greaves, W. (2016). Securing Sustainability: The Case for Critical Environmental Security in the Arctic. Polar Record, 52(6):660-671.

13. Hastrup, K., Rieffestahl, A. M., Olsen, A. (2016). Food Security: Health and Environmental Concerns in the North. In: Singer M. (Ed.), A Companion to the Anthropology of Environmental Health, John Wiley and Sons, Hoboken, NJ, USA, pp. 257-280.

14. Ignateva, V. (2018). Sakha Republic (Yakutia): Local Projections of Climate Changes and Adaptation Problems of Indigenous Peoples. In: Hiyama, T., Takakura, H. (Eds.), Global Warming and Human-Nature Dimension in Northern Eurasia, Springer, Singapore, pp. 11-28.

15. Ivanov, V., Ivanova, E. (2017). Arctic Specifics of Food Supply and Development of Agriculture of the European North-East of Russia. The Arctic: Ecology and Economy, 26(2):117-130.

16. Lambden, J., Receveur, O., Marshall, J., Kuhnlein, H. V. (2006). Traditional and Market Food Access in Arctic Canada is Affected by Economic Factors. International Journal of Circumpolar Health, 65(4):331-340.

17. Loring, P. A., Gerlach, C. (2015). Searching for Progress on Food Security in the North American North: A Research Synthesis and Meta-Analysis of the PeerReviewed Literature. Arctic, 68(3):380-392.

18. Moe, A. (2014). The Northern Sea Route: Smooth Sailing Ahead? Strategic Analysis, 38(6):770-783.

19. Nilsson, L. M., Berner, J., Dudarev, A. A., Mulvad, G., Odland, J. O., Parkinson, A., Rautio, A., Tikhonov, C., Evengard, B. (2013). Indicators of Food and Water Security in an Arctic Health Context: Results from an International Workshop Discussion. International Journal of Circumpolar Health, 72(1):1-9, doi:10.3402/ ijch.v72i0.21530

20. Power, E. M. (2008). Conceptualizing Food Security for Aboriginal People in Canada. Canadian Journal of Public Health, 99(2):95-97.

21. Ready, E. (2016). Challenges in the Assessment of Inuit Food Security. Arctic, 69(3):266-280. 
22. Revich, B., Chashchin, V., Kharkova, T., Kvasha Y., Bogoyavlensky, D., Tronin, A., Tokarevich, N., Buzinov, R., Kershengolts, B., Chernyavskiy, V., Nikiforov, O., Repin, V. (2008). Climate Change Impact on Public Health in the Russian Arctic. United Nations in the Russian Federation, Moscow, Russian Federation.

23. Rylander, C., Odland, J. O., Sandanger, T. M. (2011). Climate Change and Environmental Impacts on Maternal and Newborn Health with Focus on Arctic Populations. Global Health Action, 4:1-11, doi:10.3402/gha.v4i0.8452.

24. Sonne, C., Letcher, R. J., Jenssen, B. M., Desforges, J. P., Eulaers, I., AndersenRanberg, E., Gustavson, K., Styrishave, B., Dietz, R. (2017). A Veterinary Perspective on One Health in the Arctic. Acta Veterinaria Scandinavica, 59(84):1-11.

25. Tutelyan, V. (1996). Nutrition and Health of Far North Population: Priority Directions. Occupational Health and Industrial Ecology, 6:16-19.

26. UNEP (2009). Stockholm Convention on Persistent Organic Pollutants (POPs) as Amended in 2009. United Nations Environment Programme (UNEP), Geneva, Switzerland, available at: www.wipo.int/edocs/trtdocs/en/unep-pop/trt unep pop_2.pdf

27. Vinokurova, L. (2011). Rural Yakutia: Perception Indigenous Population Changes in Environment. Arctic and North, 4:1-8.

28. Wesche, S. D., Chan, H. M. (2010). Adapting to the Impacts of Climate Change on Food Security among Inuit in the Western Canadian Arctic. EcoHealth, 7(3):361-373.

29. Willows, N. D. (2005). Determinants of Healthy Eating in Aboriginal Peoples in Canada. Canadian Journal of Public Health, 96:32-36.

30. Young, K., Carraher, S, Goodman, K. J. (2015). Inuit Health Survey. In: Stern, G., Gaden, A. (Eds.), From Science to Policy in the Canadian Western and Central Canadian Arctic: An Integrated Regional Impact Study (IRIS) of Climate Change and Modernization, ArcticNet, Quebec, Canada, pp. 255-269. 